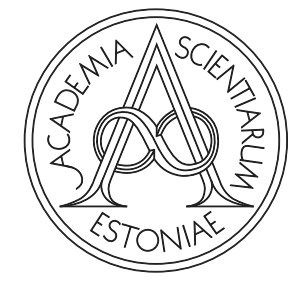

Proceedings of the Estonian Academy of Sciences, $2021,70,4,508-515$

https://doi.org/10.3176/proc.2021.4.19

Available online at www.eap.ee/proceedings

\title{
Thermal properties of calcium-aluminate based materials
}

\author{
Priit Kulu $^{\mathrm{a}}$, Dmitri Goljandin ${ }^{\mathrm{a}^{*}}$, Rainer Traksmaa ${ }^{\mathrm{a}}$, Tiit Kaljuvee ${ }^{\mathrm{b}}$ and Andre Gregor ${ }^{\mathrm{b}}$ \\ a Department of Mechanical and Industrial Engineering, Tallinn University of Technology, Ehitajate tee 5, 19086 Tallinn, Estonia \\ ${ }^{\mathrm{b}}$ Department of Materials and Environmental Technology, Tallinn University of Technology, Ehitajate tee 5, 19086 Tallinn, Estonia
}

Received 13 July 2021, accepted 26 July 2021, available online 10 November 2021

(C) 2021 Authors. This is an Open Access article distributed under the terms and conditions of the Creative Commons AttributionNonCommercial 4.0 International License (http://creativecommons.org/licenses/by-nc/4.0/).

\begin{abstract}
Good cementing properties, fast setting and strong thermal performance make calcium aluminate a valuable raw material for use in the production of different types of new refractory materials, e.g., heat conductive/storage materials. The main aim of the study was to determine thermal properties of novel $\mathrm{Nb}$-slag based materials with different fillers, and to clarify the optimal composition and technology. The preparation process of the studied materials was the following: mixing of components, casting into moulds and hardening of materials. To estimate potential application areas, the following thermal properties of CA-based materials were investigated: thermal behaviour, the coefficient of thermal expansion (CTE) and conductivity. For thermal analysis, small cylindrical specimens were cut out from produced materials, and plates sized $25 \times 300 \times 300 \mathrm{~mm}$ were used for conductivity studies. Different compositions of CA-based materials, the hardening process, and the influence of mechanical activation on the strength were analysed. The best thermal properties similar to the analogous reference materials were obtained by quartz sand and granite sand as filler materials. The thermal conductivity of the novel CA-based material is 1.5 times higher and the bending strength is about 3 times higher compared to commercial thermoplates.
\end{abstract}

Key words: materials science, calcium aluminate, refractories, thermal properties, disintegrator milling.

\section{INTRODUCTION}

Slags from metallurgy are primarily composed of silica with concentrations of constituents such as alumina, magnesia and other components which have the potential value for application. Moreover, technologies have emerged to recycle and reuse reprocessed slag in different building materials [1]. Niobium slag resulting from the aluminothermic process at Sillamäe metallurgical plant NPM Silmet AS, Estonia, contains mainly calciumconsisting aluminate (CA) and due to incomplete calciumaluminothermic reduction some amount of the initial materials - mainly niobium oxide $\mathrm{Nb}_{2} \mathrm{O}_{5}(3-7 \%)$ and pure $\mathrm{Nb}$ up to $1 \%$ (depends on the batches) [2].

The technology of the separation of pure $\mathrm{Nb}$, based on the disintegrator treatment of CA consists of the following

\footnotetext{
${ }^{*}$ Corresponding author, dmitri.goljandin@taltech.ee
}

steps: precrushing of big pieces, disintegrator milling and separation of the milled product to fine $(<0.3 \mathrm{~mm})$ and coarse fractions $(>0.3 \mathrm{~mm})$, followed by separative milling of the coarse fraction to separate pure $\mathrm{Nb}[2,3]$ (Fig.1).

Preliminary experiments were conducted to clarify the potential application area of ground $\mathrm{CA}$ as the main component of heat accumulation and heat-transfer materials. Similar alumina-silica based ceramic materials are used for accumulation (slow heat release) of heat in fireplace stoves and fireplaces [4]. Due to analogous compositions of niobium slag, it may be a potential material for refractory products.

It was demonstrated by our previous experiments [2,3] that CA-based materials have a high potential of application as the main component of refractory materials, especially in the form of heat transfer elements of stoves, fireplaces, etc. Our preliminary experiments showed that 


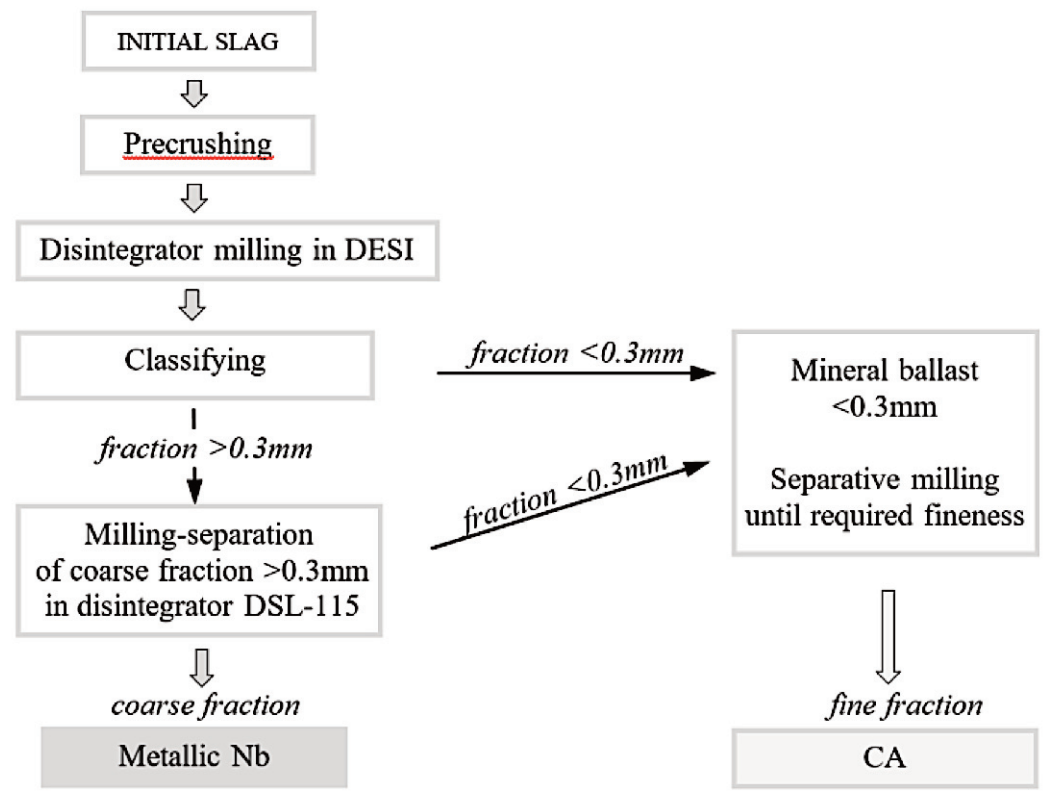

Fig. 1. Proposed scheme of milling of niobium slag and separation of metallic $\mathrm{Nb}$.

CA-based materials have high mechanical properties and similar heat conductive properties (about $0.34 \mathrm{~W} \cdot \mathrm{m}^{-1} \mathrm{~K}^{-1}$ against $0.42 \mathrm{~W} \cdot \mathrm{m}^{-1} \mathrm{~K}^{-1}$ of commercial heat-transfer materials) [2].

\section{EXPERIMENTAL}

\subsection{Initial materials}

Niobium slag was subjected to impact milling in disintegrator DESI and a coarse ground product was subjected to separative milling in disintegrator DSL-115. The ground slag contained mainly calcium aluminates (CA) - fineness was $<125 \mu \mathrm{m}$. Fresh and old CA (aged more than ten days) were used in our experiments. In order to have fresh mechanically activated CA, it was milled immediately before using (during the next $5 \mathrm{~h}$ ).

The following CA-based mixtures were studied (Table 1):

- Pure CA (fresh and old);

- CA with additions of granite sand (GS), CEN Standard quartz sand (QS) and polarstone sand (PS). The fillers were obtained by disintegrator milling of granite gravel, standard QS and PS waste. The same chemical composition was shown after milling;

- CA with the addition of fly ash cenospheres of alumina silica (AC) (lightweight, inert, hollow sphere filled with inert air or gas - a typical byproduct of coal combustion at thermal power plants [Biotecha Latvia Ltd, Riga, Latvia], mainly consisting of $\mathrm{SiO}_{2}$ and

Table 1. Composition of studied materials

\begin{tabular}{|c|c|c|}
\hline \multicolumn{2}{|c|}{ Composition [wt $\%$; conditions; fraction size] } & \multirow{2}{*}{ Post-treatment } \\
\hline $\mathrm{CA}^{\mathrm{a}}$ & Filler & \\
\hline$[100 ;$ fresh and old $]$ & - & \multirow{5}{*}{$\begin{array}{c}\text { Hardening at } \\
20^{\circ} \mathrm{C} / \text { up to } 54 \text { days }\end{array}$} \\
\hline$[66,50$ and 34 ; fresh $]$ & granite sand (GS) $[34,50$ and $66 ;$ milled; $<125 \mu \mathrm{m}]$ & \\
\hline$[66,50$ and $34 ;$ fresh $]$ & quartz sand (QS) $[33,50$ and 66 ; milled; $<125 \mu \mathrm{m}]$ & \\
\hline$[66,50$ and $34 ;$ fresh $]$ & polarstone (PS) [33, 50 and 66 ; milled; $<125 \mu \mathrm{m}]$ & \\
\hline [75 (50 vol\%); fresh] & ash cenospheres (AC) $[25$ (50 vol\%); classified; $<300 \mu \mathrm{m}]$ & \\
\hline- & portland cement $[25]+$ standard sand $[75 ; 2 \div 0 \mathrm{~mm}]$ & $\begin{array}{c}\text { Hardening at } \\
20^{\circ} \mathrm{C} / 7 \text { days }\end{array}$ \\
\hline
\end{tabular}


$\mathrm{Al}_{2} \mathrm{O}_{3}$ ). The chemical composition of $\mathrm{AC}$ was studied previously in [5] and it has been approved as an efficient heat-resistant inert filler for ceramics [6] and lightweight concrete [7]. Figure 2 shows the SEM images of the filler materials used.

As a reference material, an analogous Cebud thermoplate CPA-K [8] and concrete (cement + standard sand) of hardened materials were prepared and tested for comparison.

For the study of mechanical properties, bending strength specimens sized $40 \times 40 \times 160 \mathrm{~mm}$ were prepared. For the thermal analysis, cylindrical specimens with $\varnothing 7 \mathrm{~mm}$ were cut out from mechanical test pieces. For the study of thermal conductivity, the plates sized $300 \times$ $300 \times 25 \mathrm{~mm}$ were produced. The prepared mixtures of CA with fillers and addition of water (about 33\%) were cast into moulds and densified by vibration. The procedure was as follows: preparation of components $\rightarrow$ mixing of mixtures $\rightarrow$ hardening at air $24 \mathrm{~h} \rightarrow$ drying at
$100{ }^{\circ} \mathrm{C}$ for $24 \mathrm{~h}$. The density of CA-based materials with the fillers GS and QS was about $2.0 \mathrm{~g} / \mathrm{cm}^{3}$, with PS it was about $1.5 \mathrm{~g} / \mathrm{cm}^{3}$ and with AC about $1.3 \mathrm{~g} / \mathrm{cm}^{3}$.

\subsection{Characterization of mechanical properties}

Prismatic specimens were tested at three-point bending on a universal testing machine according to standard EVSEN 196-1:2016 [9], determining the bend strength of the specimens. Then, the universal testing machine P-5 $(50 \mathrm{kN})$ was employed, the distance between the points of support was $100 \mathrm{~mm}$.

\subsection{Characterization of thermal properties}

The thermomechanical characteristics of the samples of heat-conductive materials were determined on Setaram Setsys 1750 CS Evolution dilatometer. Cylindrical specimens with a diameter of $7 \mathrm{~mm}$ and height of $15-16 \mathrm{~mm}$
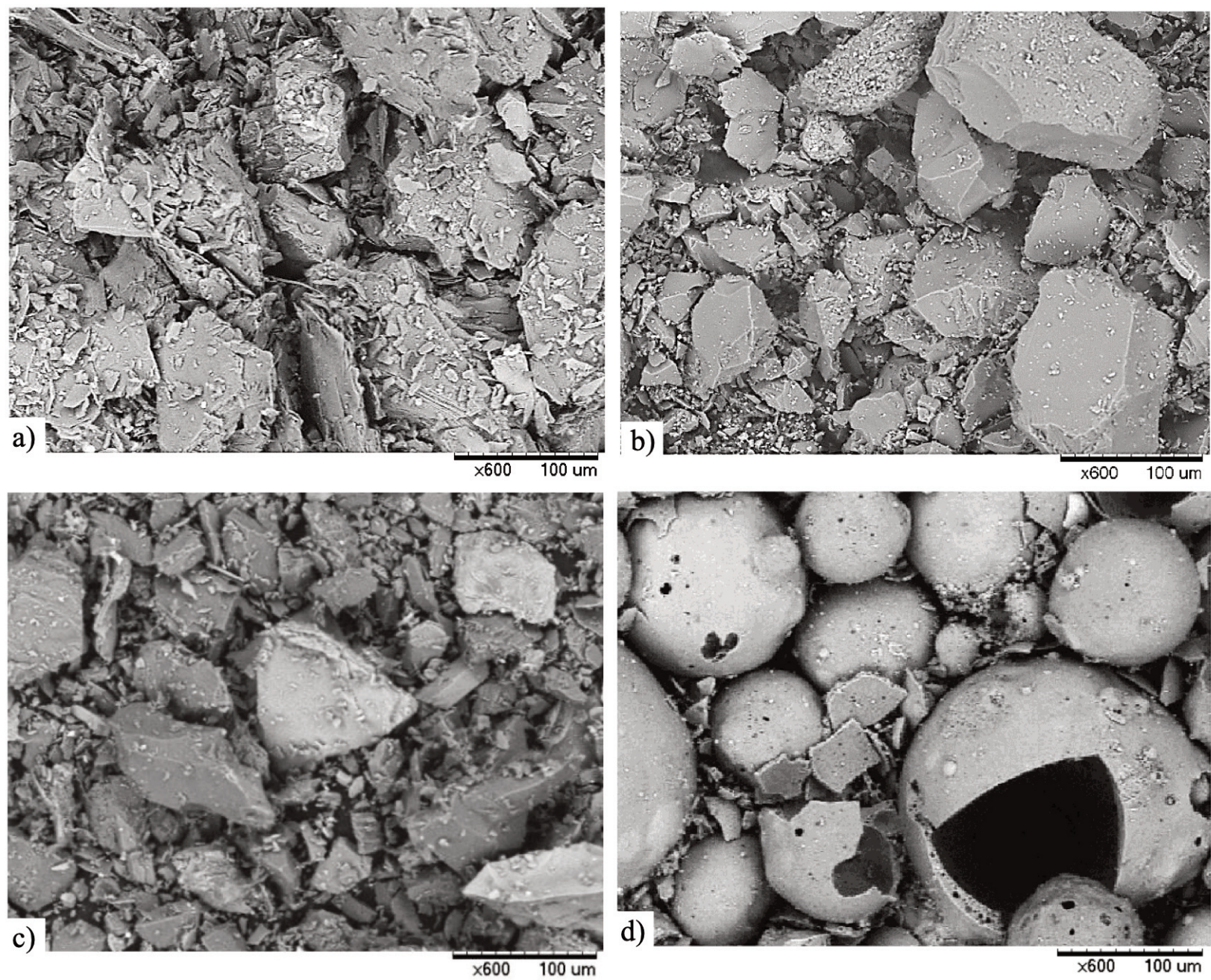

Fig. 2. Filler materials: a - granite sand, b - quartz sand, $\mathrm{c}$ - polarstone sand, $\mathrm{d}$ - fly ash cenospheres. 
in a corundum sample holder were heated up to $1000^{\circ} \mathrm{C}$ at a heating rate of $5^{\circ} \mathrm{C}$ per minute and cooled down at the same rate in an Ar atmosphere. The diagrams DTDA-T and $\Delta 1 \%$-T were plotted.

Thermal conductivity was measured according to the standard EVS-EN 12667:2001 [10] using LaserComp FOX-304 Heat Flow Meter. In a heat flow metre, a specimen is positioned between two temperature-controlled plates. These plates establish a user-defined temperature difference $(\Delta T)$ across the sample. The resulting heat flux $(\mathrm{Q} / \mathrm{A})$ from steady-state heat transfer through the specimen is measured by two proprietary thin film heat flux transducers covering a large area of upper and lower sample surfaces.

The average heat flux was used to calculate the thermal conductivity $(\lambda)$ and thermal resistance $(R)$ according to Fourier's law. For thermal plates the optimal composition of CA:Filler (50:50) was selected consider- ing technological as well as strength properties of the studied materials.

\section{RESULTS AND DISCUSSION}

\subsection{Thermal Analysis}

The DTDA-diagram shows old CA (Fig. 3), changes up to $100{ }^{\circ} \mathrm{C}$ are related to the emission of physically bound water. Changes in the range from 200 up to $400{ }^{\circ} \mathrm{C}$ are probably related to thermo-oxidation of the matter contained in Nb-slag as remains of the reduction process, and the change at $970{ }^{\circ} \mathrm{C}$ is probably caused by the formation of liquid phase.

The contraction-expansion behaviour of the samples of the studied materials by heating up to $1000{ }^{\circ} \mathrm{C}$ at the heating rate of $5^{\circ} \mathrm{C} / \mathrm{min}$ is presented in Fig. 4 .

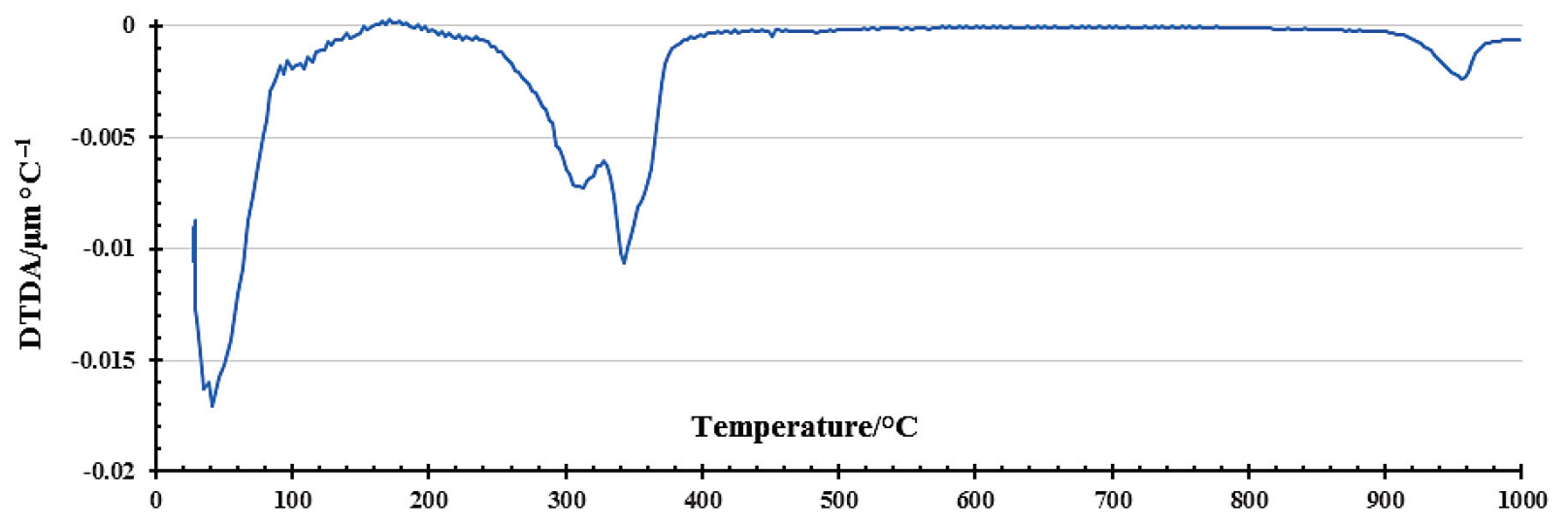

Fig. 3. Heating curve (DTDA-diagram) of CA.

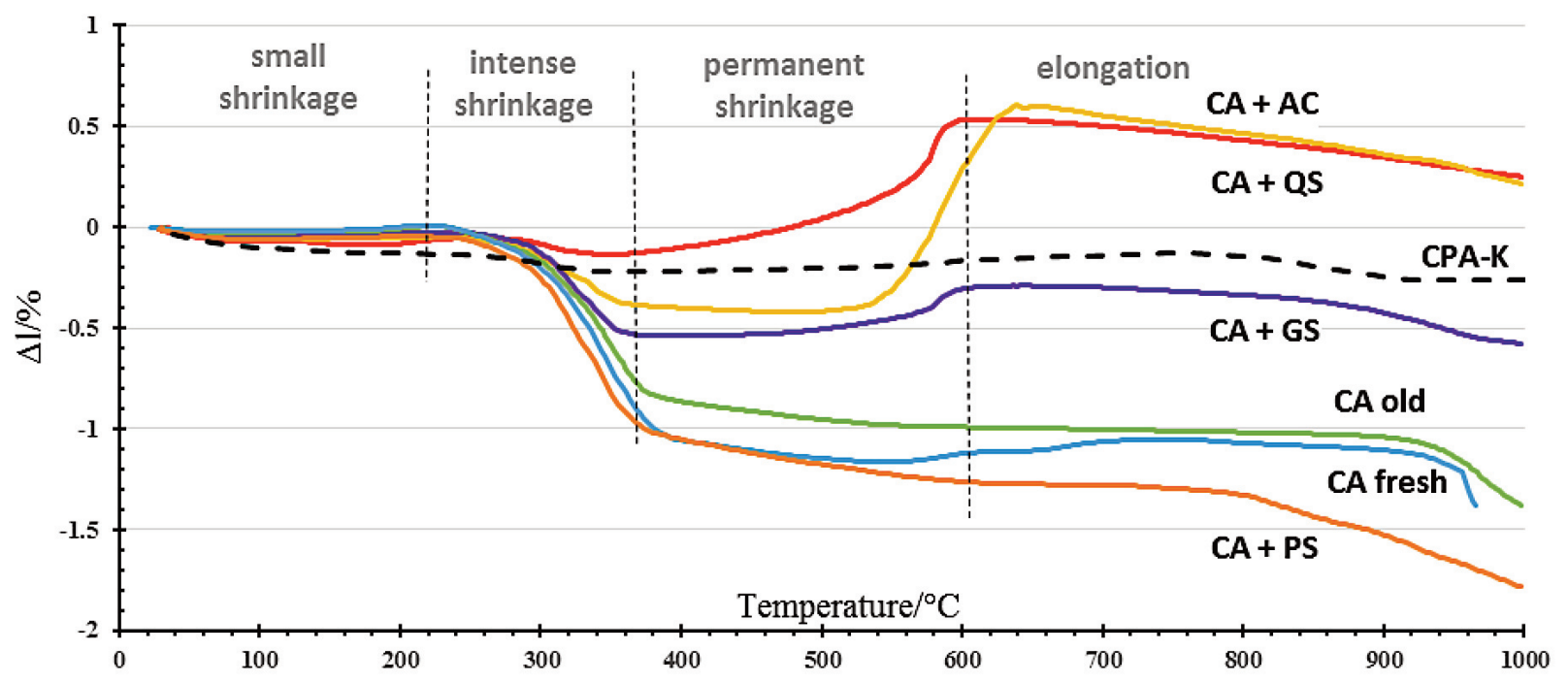

Fig. 4. Shrinkage-expansion curves of CA-based materials. 
As the graph shows, up to $180-200{ }^{\circ} \mathrm{C}$ low shrinkage (up to $-0.1 \%$ ) can occur. Then, starting from $260{ }^{\circ} \mathrm{C}$, deep shrinkage of bodies up to $340-380{ }^{\circ} \mathrm{C}$ follows, which is the most significant for pure CA (fresh $-1.03 \%$, old $-0.85 \%$ ). Starting from $400{ }^{\circ} \mathrm{C}$, stabilization takes place.

The behaviour of composites (except CA+QS) notably differs from the behaviour of pure CA. Shrinkage is less dependent on the temperature; shrinkage of $\mathrm{CA}+\mathrm{GS}$ occurs up to $360{ }^{\circ} \mathrm{C}$ (up to $-0.5 \%$ ) and then it stabilizes.

The composition containing quartz sand (CA+QS) behaves in a slightly different way: shrinkage is low $(-0.2 \%)$ up to temperature $480{ }^{\circ} \mathrm{C}$ and then an expansion follows up to $580{ }^{\circ} \mathrm{C}$ (up to $+0.5 \%$ ), after which it is stabilized. The thermal behaviour of $\mathrm{CA}+\mathrm{AC}$ body is characterized in an analogous way: starting from $550{ }^{\circ} \mathrm{C}$ notable elongation occurs $(+0.6 \%)$ and then stabilization from $600{ }^{\circ} \mathrm{C}$ up to $1000{ }^{\circ} \mathrm{C}$.

\subsection{Behaviour of $\mathrm{CA}$ in the hardening process}

Our preliminary experiments demonstrated that in the hardening process a notable increase occurs in the temperature of hardenable specimens, first, with CA that was just milled.

For this propose, a special study with pure CA with the particle size $<125 \mu \mathrm{m}$ was carried out - old (milled earlier and aged) and fresh (just milled) CA were used. Hardening time was $16 \mathrm{~h}$.

Figure 5a illustrates that the temperature at the hardening of specimens made from fresh materials increases up to $100{ }^{\circ} \mathrm{C}$ whereas with specimens of old CA, the temperature is not significantly increased. It reveals mechanical activation in the high velocity impact milling process. The mechanical activation of materials due to the disintegrator milling was demonstrated in our earlier work $[11,12]$. It causes a notable increase in the mechanical properties as well as in the bending strength; materials made from fresh milled CA demonstrate up to 2 times higher strength

(a)

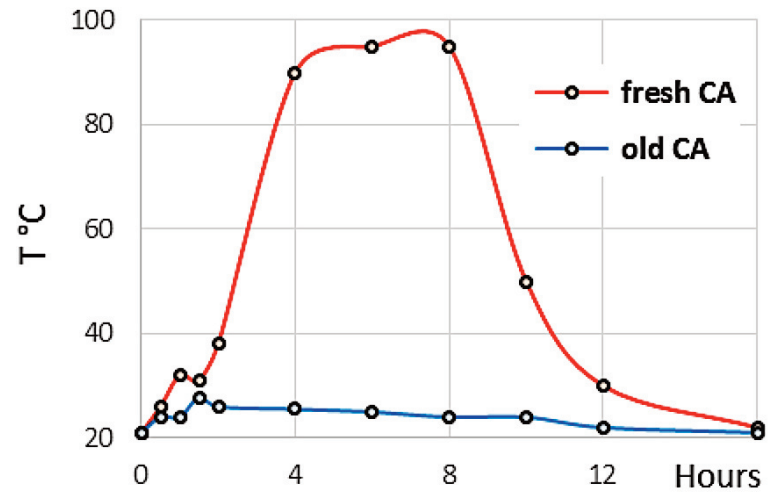

(Fig. 5b). It takes about two days to achieve the necessary minimal strength level, e.g., $4 \mathrm{MPa}$ with old CA, while with fresh CA only $10 \mathrm{~h}$ are required. One of the ways to suppress this phenomenon is to use ballast materials, i.e., inert fillers. With fillers, noticeable heating of cast mixture was not observed and was similar to old CA.

\subsection{Optimization of composition}

To suppress the high activity of fresh CA, inert filler materials such as granite sand, polarstone sand and CEN Standard sand - quartz sand were used. The studied mixtures consisted of filler materials from $33 \%$ to $66 \%$. The materials were made by the same technology: mechanical mixing of components, casting of mixtures into moulds, densification by vibration and hardening at room temperature for $24 \mathrm{~h}$, followed by drying at $100^{\circ} \mathrm{C}$ for $24 \mathrm{~h}$. Three prismatic specimens were subjected to the bend load at the three-point test. The results of the bending test are given in Fig. 6 .

At all studied compositions, increase in the filler content causes a decrease in the bending strength. In the case of fillers GS and QS with the content over $50 \%$, a deep decrease in the strength can be seen (Fig. 6a and 6b). Up to that point, with the increase of the filler content, flexural strength decreases proportionally. At the same time, the strength of materials increases with the use of fresh filler materials that were immediately disintegrator milled, being 30\% higher (GS and QS) except for PS (Fig. 5b).

Notable influence of hardening time on the strength was observed. The samples gained half of their strength in the first 14 days of hardening. Over time (42 and 56 days), the rate of increase in the flexural strength slowed down.

Adding polarstone as a filler has a strong effect on the strength. The dependence of the decrease in strength on the amount of filler has a pronounced linear character (Fig. 7).

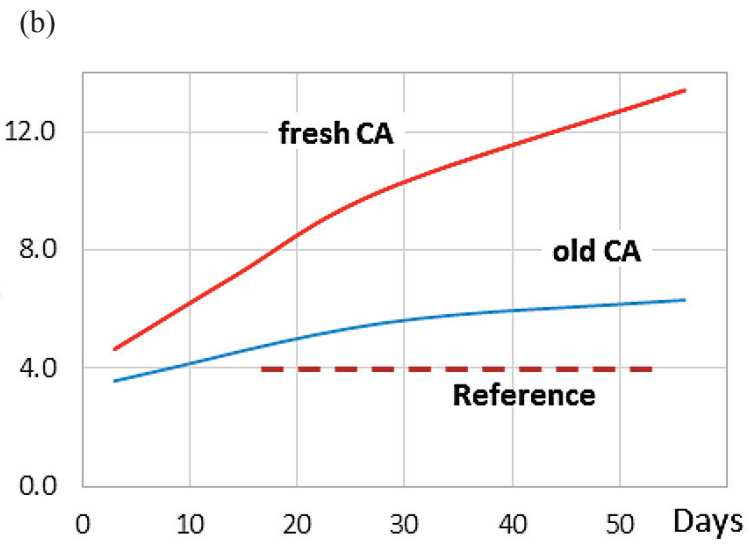

Fig. 5. Influence of mechanical activation on the behaviour and properties of CA: (a) self-heating at the hardening process; (b) increase in flexural strength Rf during hardening. 
(a)

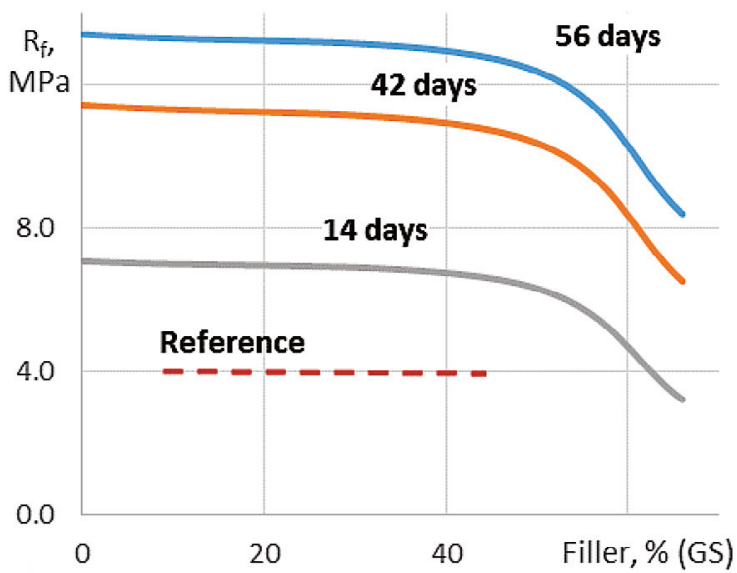

(b)

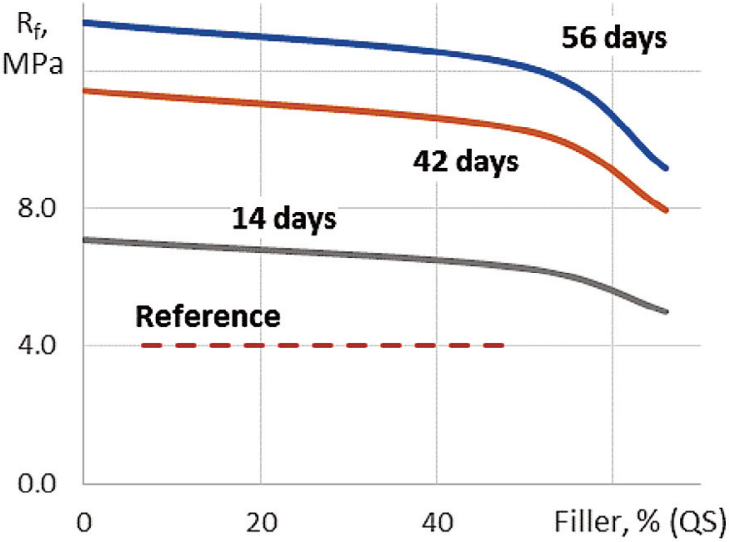

Fig. 6. Dependence of flexural strength on the amount of filler in the mixture: a - granite sand, b - quartz sand.

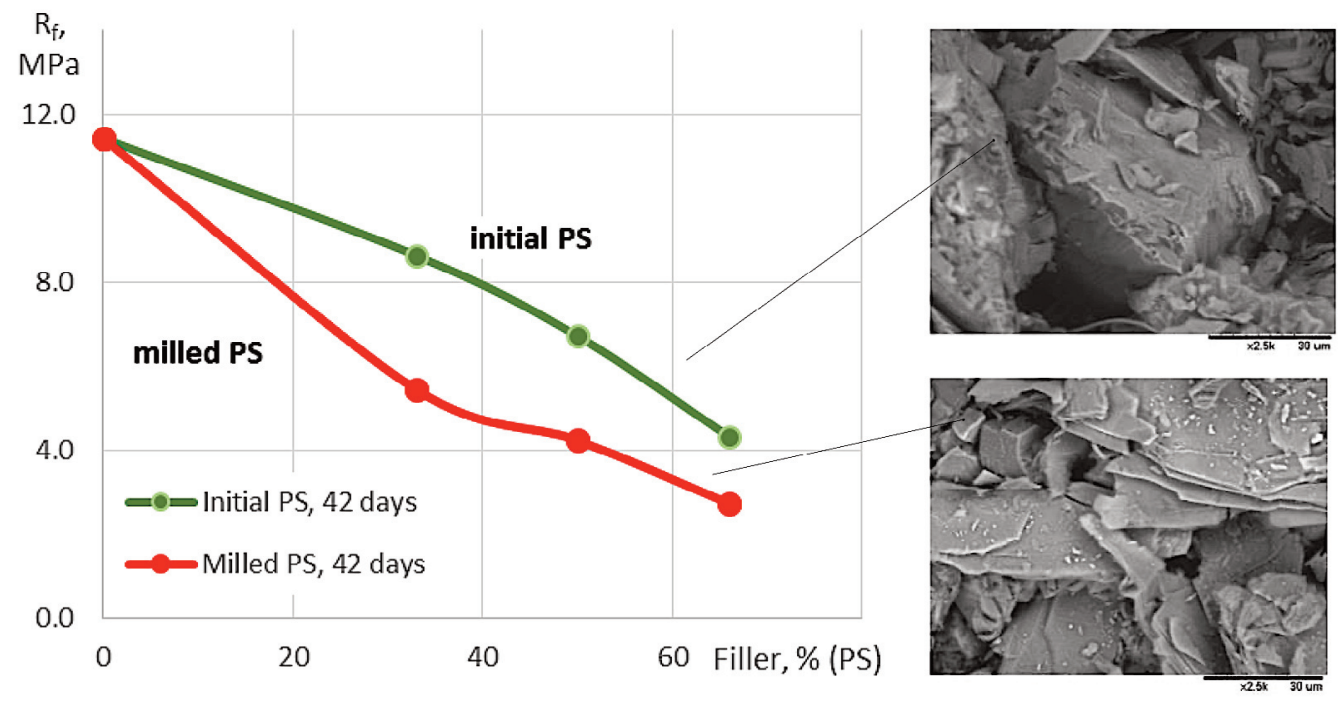

Fig. 7. Dependence of flexural strength on the amount of polarstone in the mixture.

Better strength was observed when using a non-milled PS filler, which can be explained by a change in the morphology of PS particles as a result of milling. Due to the lamellar structure of PS particles, we obtained flake powder (Fig. 7).

\subsection{Thermal conductivity of $\mathrm{CA}$-based materials}

The results of the thermal conductivity study are provided in Fig. 8 and Table 2. The figure indicates that the CA+QS material has better conductivity, being about $55 \%$ higher than the reference material CPA-K, followed by the $\mathrm{CA}+\mathrm{GS}$ material (about 29\% higher) and CA+PS (10\% higher).
Taking into account the mechanical and thermal properties as well as the economic aspect, CA-based materials with a quartz sand filler are more prospective.

\section{CONCLUSIONS}

1. Novel calcium-aluminate (CA) - Nb-slag based materials were obtained and prospects for application as heat conductive materials have been demonstrated.

2. Based on the study of mechanical and thermal properties of CA-based materials of different compositions and conditions, we can draw the following conclusions: 


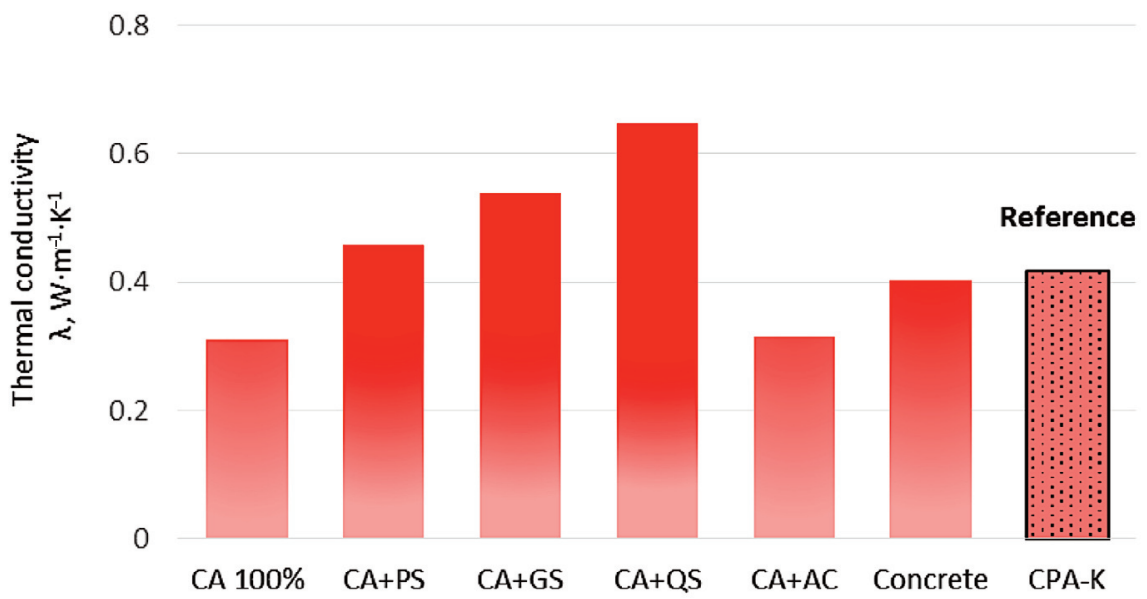

Fig. 8. Thermal conductivity of CA-based materials.

Table 2. Thermal conductivity and density of different compositions compared to the reference material

\begin{tabular}{l|c|c|c}
\hline \multicolumn{1}{c|}{$\mathrm{CA}<125 \mu \mathrm{m}$} & $\begin{array}{c}\text { Density } \\
\mathrm{g} / \mathrm{cm}^{3}\end{array}$ & $\begin{array}{c}\text { Thermal conductivity } \lambda \\
\mathrm{W} /(\mathrm{m} \cdot \mathrm{K})\end{array}$ & $\begin{array}{c}\lambda \text { compared to } \\
\mathrm{CPA}-\mathrm{K}\end{array}$ \\
\hline $\mathrm{CA}$ old & 1.9 & 0.34 & $25 \%$ lower \\
$\mathrm{CA}$ fresh milled & 2.0 & 0.31 & $25 \%$ lower \\
$\mathrm{CA}+\mathrm{PS}^{*}$ & $1.4 \div 1.6$ & 0.46 & $10 \%$ higher \\
$\mathrm{CA}+\mathrm{GS}^{*}$ & $1.6 \div 1.7$ & 0.54 & $29 \%$ higher \\
$\mathrm{CA}+\mathrm{AC}^{*}$ & $1.2 \div 1.3$ & 0.31 & $25 \%$ lower \\
$\mathrm{CA}+\mathrm{QS}^{*}$ & $1.8 \div 2.0$ & 0.65 & $55 \%$ higher \\
$\mathrm{Concrete}$ & 2.0 & 0.40 & about the same \\
CPA-K & $2.0 \div 2.1$ & 0.42 & Reference \\
${ }^{*}$ Filler content $50 \%$ & & &
\end{tabular}

- Mechanical milling of CA is accompanied by activation of the ground material due to the fresh surfaces formed. As a result, this hardening process is more intensive, producing higher strength (up to 2 times). At the same time, an increase in the temperature in the hardening process results in the decrease in density and distortion of the material. It can be suppressed by optimizing the composition by the use of fillers.

- Optimal CA : filler proportion in fresh CA-based materials is $40-50 \%: 60-50 \%$. Increase in strength by using a filler is about $10-15 \%$ (for GS) and $25-30 \%$ for QS and PS.

- With regard to thermal properties, the composition of CA with granite and quartz sand fillers is favourable. The thermal conductivity properties are $30-50 \%$ higher and strength properties about 3 times higher than these of the reference thermoplates.

\section{ACKNOWLEDGEMENTS}

This work was supported by the Estonian Research Council grant PRG643 and by the Environmental Investment Centre Foundation grant KIK17660. The publication costs of this article were covered by the Estonian Academy of Sciences and Tallinn University of Technology.

\section{REFERENCES}

1. Batalin, B. Harm and benefits of slags landfills. J. Nature, 2001, 1(10), 162-165.

2. Kulu, P., Goljandin, D., Külaviir, J., Hain, T. and Kivisto, M. Recycling of niobium slag by disintegrator milling. Key Eng. Mater., 2019, 799, 97-102. https://doi.org/10.4028/www. scientific.net/KEM.799.97

3. Kulu, P., Goljandin, D., Viljus, M., Traksmaa, R. and Gregor, A. Heat conductive plates from recycled niobium 
slag. Solid State Phenom., 2021, 320, 169-175. https://doi.org/ 10.4028/www.scientific.net/ssp.320.169

4. EVS-EN ISO 10081-1:2005. Classification of dense shaped refractory products - Part 1: Alumina-silica.

5. Shishkin, A., Mironov, V., Zemchenkov, V., Antonov, M. and Hussainova, I. Hybrid syntactic foams of metal - fly ash cenosphere - clay. Key Eng. Mater., 2016, 674, 35-40. https://doi.org/10.4028/www.scientific.net/kem.674.35

6. Rugele, K., Lehmhus, D., Hussainova, I., Peculevica, J., Lisnanskis, M. and Shishkin, A. Effect of fly-ash cenospheres on properties of clay-ceramic syntactic foams. Materials, 2017, 10(7), 828. https://doi.org/10.3390/ma10070828

7. Baronins, J., Setina, J., Sahmenko, G., Lagzdina, S. and Shishkin, A. Pore distribution and water uptake in a cenosphere-cement paste composite material. IOP Conf. Ser. Mater. Sci. Eng., 2015, 96, 012011. https://doi.org/10.1088/ 1757-899X/96/1/012011
8. Cebud. Fireplace stoves made of Akubet. http://cebud.eu/en

9. CEN Standard EN 196-1:2016. Methods of testing cement Part 1: Determination of strength.

10.Standard EVS-EN 12667:2001. Thermal performance of building materials and products - Determination of thermal resistance by means of guarded hot plate and heat flow meter methods - Products of high and medium thermal resistance.

11.Bumanis, G., Bajare, D. and Goljandin, D. Performance evaluation of cement mortar and concrete with incorporated micro fillers obtained by collision milling in disintegrator. Ceramics-Silikáty, 2017, 61(3), 231-243. https://doi.org/ 10.13168/cs.2017.0021

12.Goljandin, D. and Kulu, P. Disintegrators and Disintegrator Treatment of Materials. LAP LAMBERT Academic Publishing, Saarbrücken, 2015.

\section{Kaltsiumaluminaadi baasil materjalide soojusomadused}

\section{Priit Kulu, Dmitri Goljandin, Rainer Traksmaa, Tiit Kaljuvee ja Andre Gregor}

Kaltsiumaluminaadi (CA) teeb väärtuslikuks toormeks mitmesuguse kuumuskindla ehituskeraamika valmistamisel selle head tsementeerivad omadused, kiire kivistumine ja hea termopüsivus.

Käesoleva töö eesmärgiks on olnud uurida põhikomponendina kaltsiumaluminaati sisaldava nioobiumräbu (Nbräbu) baasil mitmesuguse täiteainega materjalide soojusomadusi, määratlemaks nende optimaalset koostist ja tehnoloogiat.

Nb-räbu ümbertöötlus sisaldas järgmisi etappe: peenendamine, eeljahvatus, separatsioonjahvatus nioobiumi eraldamiseks ja CA peenfraktsiooni saamiseks. Materjalide valmistustehnoloogia oli järgmine: komponentide segamine, valamine vormidesse koos vibrotihendamisega ja kuivatamine koos kivistumisega. Hindamaks uudse materjali potentsiaalseid kasutusvõimalusi, uuriti järgmisi soojusomadusi: termopüsivus, soojuspaisumine ja soojusjuhtivus. Selleks valmistati termoanalüüsi tarvis silindrilised proovikehad läbimõõduga $7 \mathrm{~mm}$ ja soojusjuhtivuse määramiseks plaadid mõõtmetega $25 \times 300 \times 300 \mathrm{~mm}$. Uuriti CA-baasil materjalide erinevaid koostisi, täiteaineid, mehaanilise aktivatsiooni ja kivistumisprotsessi mõju materjalide tugevusele ja soojusjuhtivusele. Parimate mehaaniliste ja soojusomadustega materjal, lähedane kaubanduslikele plaatidele, saadi peene CA ja täiteainena kvarts- ja graniitliiva kasutamisel. Uudsete soojusplaatide mehaaniline tugevus oli umbes kolm korda kõrgem ja soojusjuhtivus umbes 1,5 korda parem, võrreldes kaubandusliku CPK termoplaadiga. 